\title{
A Case of Insulinoma Presenting As Circadian Rhythm Sleep Disorder
}

\author{
Takeshi Ito $^{1}$, Masayoshi Komura ${ }^{1}$, Satoru Miyatake², Hiroharu Shinozaki ${ }^{3}$ \\ Kunihiko Arai ${ }^{1}$, Mizue Yokoyama ${ }^{1}$, and Kenji Kobayashi ${ }^{2}$
}

\begin{abstract}
We report the case of a 17-year-old female first presenting as circadian rhythm sleep disorder, then later diagnosed as insulinoma. The patient demonstrated severe deterioration of academic performance in high school classes six months prior to examination. She also had disordered dietary habits, including copious late-night consumption progressing to reversal of daytime and nighttime activities. The patient was examined by a psychiatrist and diagnosed with circadian rhythm sleep disorder. Somnolence developed and worsened thereafter, and the patient was transported by ambulance to our facility. The patient was silent and almost non-verbal at admission, suggesting a mental disorder. However, hypoglycemia persisted despite the opportunity for adequate food intake after admission. Additional investigation and extensive test results showed an insulin/glucose ratio of $0.64(17.8 \mu \mathrm{U} / \mathrm{ml} / 28 \mathrm{mg} / \mathrm{dl})$. Abdominal magnetic resonance imaging $(\mathrm{MRI})$ demonstrated a $15 \times 10 \mathrm{~mm}$ tumor at the border of the pancreatic head and body. Insulinoma was diagnosed, and the tumor was excised. Hypoglycemia and circadian rhythm sleep disorder disappeared completely after surgery, and the patient was discharged. The Japanese literature shows that approximately $10 \%$ of insulinomas present various mental symptoms. Chronic hypoglycemia symptoms are also sometimes difficult to differentiate from mental disorders, and careful observation is required in emergency room settings.
\end{abstract}

(JJAAM $2007 ; 18: 47-50$ )

Key words:hypoglycemia, mental disorder, somnolence, insulin, pancreatic tumor Accepted for publication on June 13, $2006 \quad$ (06-036)

\section{Introduction}

Many patients are treated in the emergency room for complaints of various mental symptoms. When irregular symptoms are observed, it can be difficult to differentiate mental, central nervous system, and metabolic disorders, as well as the overlap thereof. The classically cited symptoms of insulinoma are Whipple's triad: ${ }^{1)}$ (1) Symptoms are known or are likely to be caused by hypoglycemia. (2) A low glucose level was measured at the time of symptoms ( $<50 \mathrm{mg} / \mathrm{dl}$ ). (3) Relief from symptoms occurs when glucose level is raised to normal. However, insulinoma sometimes presents as mental disorders and is a condition

\footnotetext{
${ }^{1}$ Department of Internal Medicine, Saiseikai Utsunomiya Hospital ${ }^{2}$ Department of Emergency Medicine, Saiseikai Utsunomiya Hospital ${ }^{3}$ Department of Surgery, Saiseikai Utsunomiya Hospital Correspondence Author: Takeshi Ito, Department of Internal Medicine, Saiseikai Utsunomiya Hospital 911-1 Takebayashi, Utsunomiya, Tochigi 321-0974, Japan
}

easily misdiagnosed ${ }^{2)}$. We report a case of insulinoma presenting as circadian rhythm sleep disorder and deteriorating school performance, which was diagnosed as insulinoma from extensive test results.

\section{Case Report}

A 17-year-old female was transferred to our emergency room for a complaint of somnolence. Information ascertained from the parents was as follows. From childhood, the patient tended toward silent social closeting in her own room. High-school marks were excellent but declined suddenly six months prior to examination. Napping in school became frequent, which drew the concern of teachers. The patient also showed disordered dietary habits, including copious consumption from late night until early morning. Fixed meals were sometimes skipped in favor of computergame use. Due to persistent reversal of daytime and nighttime activity, the patient was examined by a private psychiatrist who diagnosed circadian rhythm sleep disorder. Dietary imbalance was observed, but there was no excess 


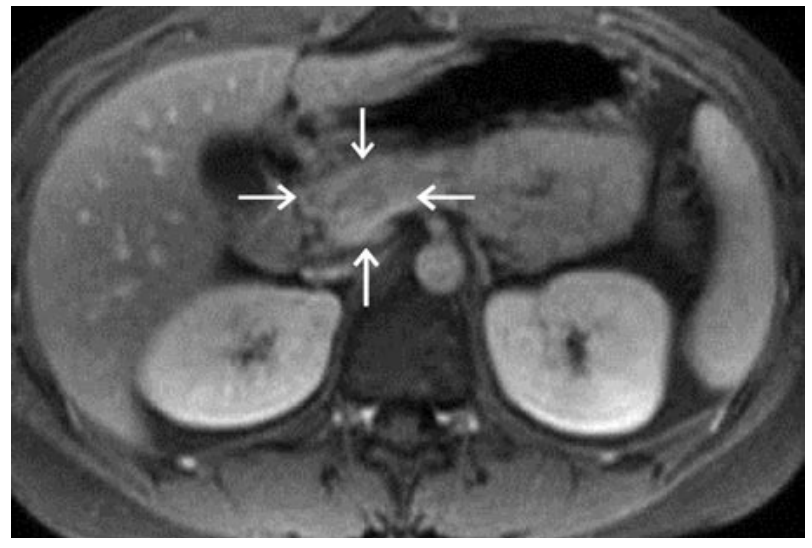

Fig. 1. Gadolinium-enhanced abdominal magnetic resonance imaging image.

caffeine consumption, smoking, or drug use. Subsequently, somnolence developed, waking ceased, and the family called an ambulance.

Vital signs at admission were as follows: Consciousness level of Japan Coma Scale (JCS) III-100 and Glasgow Coma Scale (GCS) E1 V1 M4; respiratory rate 20/min; heart rate $80 / \mathrm{min}$; blood pressure 126/74 $\mathrm{mmHg}$; body temperature $36.2{ }^{\circ} \mathrm{C}$. Physical findings on examination were $155 \mathrm{~cm}$ height, $55 \mathrm{~kg}$ weight, and Body Mass Index 22.9. There were no head wounds and no other abnormal findings.

There were no abnormal values on peripheral blood analysis and biochemical analysis of serum except for a low level of glucose $(28 \mathrm{mg} / \mathrm{dl})$. Urinalysis results showed no abnormal findings, and toxicological screening by Triage ${ }^{\circledR}$ was also negative. After intravenous injection of 40 $\mathrm{ml}$ of $40 \%$ glucose, blood sugar was $55 \mathrm{mg} / \mathrm{dl}$, and consciousness had improved to Japan Coma Scale I-1. Although the disturbance of consciousness was improved, the hypoglycemia remained unexplained, and the patient was admitted.

Even after admission, speech was virtually negligible, and communication was difficult. The initial diagnosis was therefore schizophrenia, circadian rhythm sleep disorder, eating disorder, or another such mental disorder. Questioning indicated that the patient withdrew into her own room and pursued irregular activities to the point of daytime and nighttime reversal, sometimes not eating for up to 20 hours, which was the assumed cause of hypoglycemia. However, hypoglycemia persisted even after admission, despite the opportunity for regular and adequate oral intake, and the cause was further investigated.

Additional test results predicated on insulinoma were

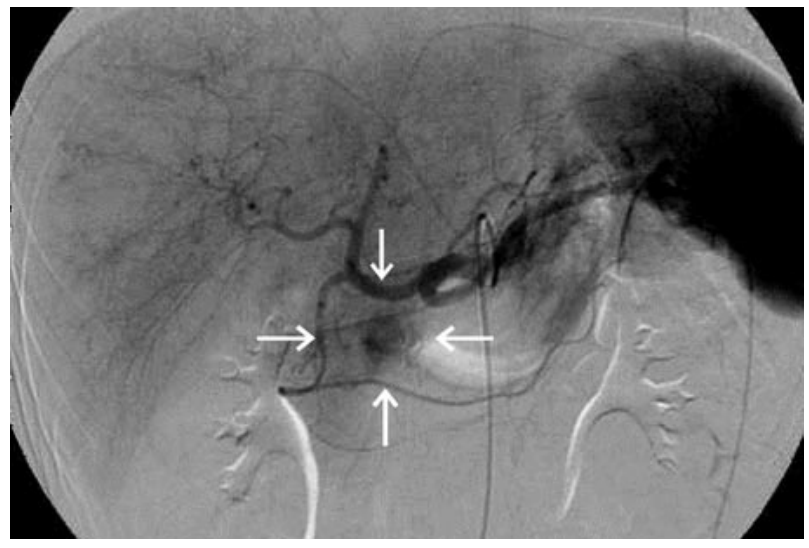

Fig. 2. Selective angiography findings for the celiac artery.

as follows: Blood insulin/glucose (IRI / glu) ratio was 0.64 $(17.8 \mu \mathrm{U} / \mathrm{ml} / 28 \mathrm{mg} / \mathrm{dl})>0.3$. Insulin during hypoglycemia was IRI $10.9 \mu \mathrm{U} / \mathrm{ml}>6$, and C-peptide CPR during hypoglycemia was $4.56 \mathrm{ng} / \mathrm{ml}>0.6$. Blood insulin and Cpeptide values were high despite low blood sugar, clearly fulfilling the 1976 diagnostic criteria of Fajans et al ${ }^{3)}$ and the 1995 diagnostic criteria of Service ${ }^{4)}$ for blood testing.

Enhanced abdominal computed tomography did not show a pancreatic tumor. Nonetheless, abdominal MRI demonstrated a weak T1-weighted signal at the border of the pancreatic head and body, a $15 \times 10 \mathrm{~mm}$ lesion slightly enhanced by gadolinium (Fig. 1).

Selective angiography findings for the celiac artery demonstrated a $15 \mathrm{~mm}$ diameter hypervascular tumor supplied by the dorsal pancreatic artery (Fig. 2).

Accordingly, pancreatic endocrine tumor and insulinoma were diagnosed. The pituitary gland, thyroid gland, parathyroid gland, and adrenal gland were normal, negating multiple endocrine neoplasia.

The clinical diagnosis was insulinoma, and limited resection of the tumor was performed. The pathological diagnosis of the specimen was insulinoma. Hypoglycemia and circadian rhythm disturbance disappeared completely after surgery, and the patient was discharged.

\section{Discussion}

This case included late night waking activity and overeating, leading at times to excess drowsiness during school classes and impairment of social activities. A discrepancy consequently developed between the circadian sleep rhythm of the patient and the schedule imposed environmentally. Based on the diagnostic criteria of the Diagnos- 
Table 1. Case reports of insulinoma distinguished with difficulty from mental disorders in Japan.

\begin{tabular}{cclclc}
\hline Age & Sex & Misdiagnosed Insulinoma cases & Interval to diagnosis & Journal of Publication \\
\hline 25 & Male & Epilepsy & 4 month & J Med Soc South Hokkaido \\
50 & Male & Confusional arousal & 4 month & Jpn J Clin Psychiatry \\
29 & Female & Schizophrenia, Hallucination, Delusion & 3 months & Clinic All-round \\
77 & Female & Dementia, Memory lapse, Depression & 3 months & Jpn J Geriat & 2000 \\
57 & Female & Depression, Epilepsy, Hysteria & 6 years & Jpn J Clin Psychiatry \\
62 & Female & Schizophrenia & 2 years & J Saitama Med Soc \\
23 & Male & Epilepsy & 2 years & Jpn J Clin Psychiatry \\
51 & Female & Menopausal disorders & 10 months & Jpn J Clin Psychiatry \\
46 & Female & Hallucination & 1 year & Jpn J Clin Psychiatry \\
28 & Female & Memory lapse, Anorexia nervosa & 7 months & Bull Kanagawa Psychiatr Assoc \\
62 & Female & Memory lapse, Wandering & 8 years & The Biliary tract \& pancreas \\
\hline
\end{tabular}

tic and Statistical Manual of Mental Disorders, Fourth Edition $^{5)}$, a circadian rhythm sleep disorder was diagnosed.

Insulinoma is an endocrine tumor causing hypoglycemia. In an investigation ${ }^{6)}$ of 358 cases of insulinoma during the 10-year period of 1991-2000, symptoms at the initial manifestation of insulinoma included many attributable to hypoglycemia; the most frequent being loss of consciousness $(28.2 \%)$ and disturbance of consciousness (16.8\%), followed by hypoglycemia (15.4\%), convulsions (4.7\%), and sweating. However, note should be taken that approximately $10 \%$ of these cases included various mental symptoms not initially suggestive of hypoglycemia, including behavioral abnormalities (3.9\%), drowsiness $(1.4 \%)$, irritation $(1.1 \%)$, memory lapse $(0.8 \%)$, sleep daze $(0.6 \%)$, insomnia $(0.3 \%)$, wandering $(0.3 \%)$, soliloquy $(0.3 \%)$, delirium $(0.3 \%)$, and depression $(0.3 \%)$. Previous, separate statistical research studies ${ }^{7-9)}$ also indicated a largely similar pattern.

The cases diagnosed after more than a year of neurological treatment as epilepsy, dementia, schizophrenia, and other such disorders should also be noted. Table 1 shows literature search results for Japanese case reports of insulinoma difficult to differentiate from mental disorders and other such causes. Academic presentations in psychology have also described cases in which unidentified complaints existing for more than a year were treated with antipsychotics and antiepilepsy drugs, while hypoglycemia was never checked; cases difficult to differentiate from senile dementia; and cases overlapping mental handicap.

In the case of our experience, lucidity of consciousness was restored after excision of insulinoma, and speech returned gradually. The fact that, in this case, school performance that was formerly excellent deteriorated rapidly makes it highly plausible in our opinion that onset occurred not in childhood, but approximately six months previously. Some reports ${ }^{10,11)}$ concerning brain damage caused by hypoglycemia in elderly individuals suggests that, in diabetic patients, dementia may be caused by the persistence of chronic unperceived hypoglycemia. We experienced a case of insulinoma manifested as circadian rhythm sleep disorder and decreased academic performance.

The diagnosis of hyperinsulinemic hypoglycemia is often delayed. Reported intervals from onset of symptoms to time of diagnosis range from 10 days to more than 20 years. We inferred that some factors for recognition of insulinoma are as follows: 1) Many physicians do not suspect insulinoma because its incidence is very low. 2) Many physicians cannot detect tumors by abdominal echography testing because small tumors often grow slowly, and glucose and insulin levels are usually not examined all at once. 3) Counterregulatory hormonal responses camouflage symptoms of hypoglycemia and diminish the deterioration of cognitive function during hypoglycemia. Symptoms from chronic hypoglycemia are therefore difficult to differentiate from mental disorders, and careful observation is required in emergency room settings.

\section{References}

1) Whipple AO: The surgical therapy of hyperinsulinismus. J Int Chir 1938; 3: 237-76.

2) Breidahl HD, Rynearson EH: Clinical aspects of hyperinsulinism. J Am Med Assoc 1956; 160: 198-204.

3) Fajans SS, Floyd JC Jr: Fasting hypoglycemia in adults. N Engl J Med 1976; 294: 766-72.

4) Service FJ: Hypoglycemic disorders. N Engl J Med 1995; 332: 1144-52.

5) The American Psychiatric Association: Diagnostic and Sta- 


\section{Takeshi Ito, et al}

tistical Manual of Mental Disorders, Fourth Edition, Washington D.C.

6) Tsuzuki Y, Ishii H: Insulinoma- a statistical review of 358 cases of insulinoma reported from 1991 to 2000 in Japan. Nippon Rinsho 2001; 59 Suppl 8: 121-31. (in Japanese)

7) Howard JM, Moss NH, Rhoads JE: Hyperinsulinism and islet cell tumors of the pancreas; with 398 recorded tumors. Int Abstr of Surg 1950; 90: 417-55.

8) Laurent J, et al: Hypoglicemic Tumors. Excerpta Medica, Amsterdam, 1971.

9) Stefanini P, Carboni M, Patrassi N, et al: Beta-islet cell tu- mors of the pancreas: results of a study on 1,067 cases. Surgery $1974 ; 75:$ 597-609.

10) Langan SJ, Deary IJ, Hepburn DA, et al: Cumulative cognitive impairment following recurrent severe hypoglycemia in adult patients with insulin-treated diabetes mellitus. Diabetologia 1991; 34: 337-44.

11) Ryan CM, Williams TM, Finegold DN, et al: Cognitive dysfunction in adults with type 1 (insulin-dependent) diabetes mellitus of long duration: effects of recurrent hypoglycemia and other chronic complications. Diabetologia 1993; 36: 329-34.

症例報告

概日リズム睡眠障害を呈したインスリノーマ

伊東 剛 ${ }^{1}$ 小村 賢祥 ${ }^{1} \quad$ 宮武 諭 ${ }^{2}$ 篠㠃 浩治 $^{3}$

荒井 邦彦 ${ }^{1}$ 横山 水映 ${ }^{1}$ 小林 健二 $^{2}$

要旨 概日リズム睡眠障害と学業成績低下で発症し, 精密検査の結果インスリノーマと診断された17歳の女性患 者を報告する。患者は幼少期より無口で自分の部屋に引きこもりがちであった。高校での学業成績は優秀であっ たが，受診する半年前から学業成績が急激に悪化した。学校では居眠りが多くなり，教師から注意されるように なった。墚夜から早朝にかけて多く食事するなど食生活が乱れた。定時の食事を摂らずにコンピュー夕をし続け ることもあった。昼夜逆転の生活が続いたため，精神科の開業医を受診し，DSM-IV 診断基準により概日リズム 睡眠障害と診断されていた。その後, 傾眠がちとなり覚醒しなくなったため, 家族が救急車を要請し当院救急外 来へ搬送された。入院時より無口で殆ど口を利かず, 統合失調症・概日リズム睡眠障害・摄食障害など精神障害 が疑われた。しかし入院後に十分な食事を摂ることが出来るようになったにも拘わらず低血糖が続いたため，更 に原因検索を行った。血中インスリン $17.8 \mu \mathrm{U} / \mathrm{ml} /$ 血糖 $28 \mathrm{mg} / \mathrm{dl}=0.64$ 。腹部 MRIで膵頭部・体部境界にガドリ ニウムで造影される $15 \times 10 \mathrm{~mm}$ の腫瘤あり。インスリノーマと診断し, 腫瘍核出術が行われた。手術後, 低血糖 および概日リズム睡眠障害は消失・軽快し退院した。救急外来には，様々な精神症状を主訴に受診する患者も多 い。時に精神疾患なのか, 中枢神経系疾患や代謝性疾患なのか, またそれらのオーバーラップなのか判別が難し いこともある。インスリノーマの典型的症状はWhippleの 3 徵候といわれる。本邦に㧍ける集計ではインスリノー マが様々な精神症状で発症することが約 10\%あるとされる。精神科で年余にわたり，てんかん・認知症・統合失 調症などとして加療されたのち診断された症例報告も散見されている。慢性の低血糖症状は，ときに精神疾患と 鑑別が難しいこともあり，注意が必要である。

（日救急医会誌 $2007 ； 18 ： 47-50$ )

キーワード：低血糖，精神障害，傾眠，インスリン，膵腫瘍

${ }^{1}$ 済生会宇都宮病院内科 2 同院救急診療科 ${ }^{3}$ 同院外科

著者連絡先：于 321-0974 栃木県宇都宮市竹林町 911-1

原稿受理日：2006 年 6 月 13 日（06-036） 